\title{
Explore and evaluate organisational culture aspects that affecting lean implementation within manufacturing SMEs: the case of Saudi Arabia
}

\author{
Manufacturing Department, \\ School of Aerospace, Transport and Manufacturing, \\ Cranfield University, \\ Cranfield, Bedfordshire, \\ MK43 0AL, UK \\ Email: a.a.alkhoraif@cranfield.ac.uk \\ Email:p.mclaughlin@cranfield.ac.uk \\ *Corresponding author
}

Abdullah A. Alkhoraif* and Patrick McLaughlin

\begin{abstract}
There is a scarcity of research about cultural aspects and organisational culture related to lean implementation (LI) (Pakdil and Leonard, 2015). In order to addressing the need for organisational culture (OC) to better facilitate lean and propel its success among small and medium enterprises (SMEs) in Saudi Arabia as a case, requires a methodology which supports the research and analysis of OC. Grounded theory, action research and an inductive approach has been selected. Due to the nature of the topic requiring the exploration of culture, it is beneficial to utilise qualitative research which is provided by grounded theory that has been adopted. Thus, adhering to the grounded theory process utilising an issue focused approach (Sackmann, 1991). Semi-structured interviews, observations and focus-groups were chosen to conduct this exploratory study. 37 aspects have been identified from semi-structured interviews. All these aspects have been aggregated through focus groups to seven main themes.
\end{abstract}

Keywords: lean implementation; LI; organisational culture; OC; enablers; inhibiters; small and medium enterprises; SMEs; continues improvement; CI; King of Saudi Arabia; KSA; Saudi Arabia.

Reference to this paper should be made as follows: Alkhoraif, A.A. and McLaughlin, P. (xxxx) 'Explore and evaluate organisational culture aspects that affecting lean implementation within manufacturing SMEs: the case of Saudi Arabia', Int. J. Services and Operations Management, Vol. X, No. Y, pp.xxx-Xxx.

Biographical notes: Abdullah A. Alkhoraif is a $\mathrm{PhD}$ Researcher Assistant at the School of Aerospace Transportation and Manufacturing, Cranfield University. He obtained his BEng Engineering and Business and MSc Engineering Project Management form the Bournemouth University. Recently, he published two books in The Process of Quality Material Selection and Contractual and Sub-Contractual Risks: Project Management Perspective. He was involved in oil industry for ten years. This research presented in this article is a part of the research project of a framework to improve lean implementation by leveraging organisational culture. 
Patrick McLaughlin received his CEng, FIET, FIMechE, FHEA and MSc from the School of Aerospace Transportation and Manufacturing, Cranfield University. He is a Chartered Engineer and EurIng. He is also a Fellow of both of the Institution of Mechanical Engineers and the Institution of Engineering and Technology and a fellow of the Higher Education Academy. He received his MSc in Industrial Engineering and Production Management and Doctorate in Business Administration (DBA), both from the Cranfield. He worked at director level in manufacturing operations for over twenty years, and has been responsible for several plant-wide lean manufacturing implementations.

\section{Introduction}

The aim of lean production is that company resources should all be channelled in ways that ultimately create value for the end user (Schouteten and Benders, 2004). In essence it works towards the goal of maintaining value while doing less work and at the heart is achieving greater efficiency (Schouteten and Benders, 2004). The definition of lean provided by Corbett (2007) emphasises on lean as an integral part of the entire organisation, essentially pointing to lean as being considered more of a philosophy than just a tool or process. This is further supported by Womack and Jones (2003) who suggest that lean is becoming understood as more than just production, but an all-encompassing business ideology which incorporates all aspects of value streams as opposed to individual production processes. According to Bhamu and Sangwan (2014) lean provides a methodology by which organisations can significantly improve their responsiveness to customers while decreasing and managing costs and waste in supply and operational procedures. When Womack et al. released their book in 1992 'The Machine That Changed the World', the main message was when the concept of lean became popularised among mainstream business and expanded further into manufacturing beyond the automobile sector (Corbett, 2007). In its inception, lean was predominantly a tool focused on manufacturing processes (Wang and Huzzard, 2011). The evolution of lean has since transcended further into operational and strategic levels of organisations (Hines et al., 2004). Initial themes advocated by Womack et al. (1992) is organisational learning. 20 years on since Womac et al.'s book release the success rate of lean is still rather low (Pay, 2008; Yamamoto and Bellgran, 2010; Bhasin, 2012). Chay et al. (2015) suggests it is complicated to implement lean by merely focusing on the hard aspect (tools) without also including the soft aspects. Chase (1999) emphasises the need to view lean as a long-term strategy. Lin and Hui (1999) and Lewis (2000) are more sceptical of lean while Oliver and Hunter (1998) found no correlation between high and low users of lean and organisational performance.

\section{Lean as a holistic view}

In relation to lean and a holistic view school of thought, Bhasin and Burcher (2006) lean should be seen as a journey. This notion compliments the original view of Kaizen, the Japanese philosophy advocating small improvements made incrementally over time. It is also suggested that standardisation is another key in realising the benefits of continuous improvement thus achieving long-term improvement (Wittenberg, 1994). This is further 
reinforced by Liker (1997) who emphasises the importance of having a long-term orientation in relation to lean.

\section{Lean as an additional tool}

However, arguments against this holistic view suggest that in pursuit of 'Kaizen' and eradicating waste also caused Japan to land in a situation of 'gridlock' in which factories were needing just-in-time (JIT) inventories and there was a not enough suitable workers nor capital for investment (Cusumano, 1994). According to Cooney (2002), external factors particularly affecting JIT can be problematic as production should be levelled across the entire supply chain. In addition to this, he highlights the importance to still consider political and social forces, economic conditions and industry factors when implementing lean (Cooney, 2002). However, Lewis (2000) suggests that each company should have their own individual lean development path. He suggests that lean does not need to be viewed as an all-in or nothing approach, but he advocates that companies should carefully consider aspects such as the market in which they operate in, technological factors and supply chain (Lewis, 2000). James-Moore and Gibbons (1997) suggests that companies with very differentiated and low volume and very little repetition will more likely need to modify lean methods or consider a completely different approach. Lean's ability for cost reduction and improved flexibility is the key to providing a company with a competitive advantage despite debates surrounding lean as a holistic view or addition to current methods (Im and Lee, 1989; Lathin and Mitchell, 2001; Narasimhan et al., 2012). As continuous improvement and lean were originated in Japan in terms of waste, the Japanese refer to Muda, Mura and Muri. Mud is considered a process which does not add any value. The mud wastes were originally identified by Aiichi Ohno from Toyota. Muda waste tends to include the following categories; transport, inventory motion, waiting, overproduction, over-processing defects, talent and resources. Many lean initiatives often do not go past the stage of identifying Muda. Mura refers to unevenness which relates to production smoothing in lean operations. Muri refers to overburdening and putting extra stress on operations and workers. Lean aims to eradicate all different types of waste and inefficiency from the organisation (Hines et al., 2004).

\section{Saudi Arabia: national culture, organisational culture, and lean}

The Middle East are realising the importance of lean in order to advance operations and practices in the oil and gas industries as value adding and creating high standards in operations, (Salem et al., 2016). As most of the non-oil and gas industries are highly dependent on the oil and gas industry in the region; production advancements should naturally trickle down into the other manufacturing industries also. It is this relationship in which lean thinking enablers can create opportunities for higher operational standards. Although the business environment in Saudi Arabia and the Gulf countries is somewhat more difficult in terms of implementing lean principles compared with industries in other countries (Al-Najem et al., 2012). This is because in King of Saudi Arabia (KSA) and the Middle East countries, most industries are either directly or indirectly linked to the oil 
and gas industry. The business environment involves a finely woven network of symbiotic relationships and synergies among the industries which can in turn inhibit lean thinking and lean implementation (LI) (Chiarini, 2012). This is primarily because independent decisions cannot be made without approvals higher up. Furthermore, very little literature on LI has been done within the oil and gas sector and especially in the Gulf countries. Salem et al. (2016) aimed to asses' aspects pertaining to LI in the oil and gas industry. In his research he discovered that in the case of Qatar, which consists primarily of oil and gas companies, research showed that the majority of companies were not aware of lean (Chiarini, 2012). However, it was identified that a greater awareness of lean existed among the non-oil and gas sector (Salem et al., 2016). It was further highlighted that the awareness of lean correlated more highly among International Organization for Standardization (ISO) certified companies as a number of these certifications overlap with lean manufacturing principles (Salem et al., 2016). However, the issue identified is that an understanding of lean among the manufacturing organisations in the Gulf countries is significantly embedded in other management systems such as ISO standards, (ibid). That a failure to understand lean as an isolated philosophy creates barriers. OC has been heavily researched which also highlights its importance in organisational performance (Al-Swidi and Mahmood, 2011). Further to this, it has been identified that different regions of the world scubas the Middle East, Eastern Europe, Western Europe and Asian regions all possess uniqueness in terms of OC and national culture. Thus in order to achieve successful lean systems, each region needs to approach it in a feasible way aligning itself with its own national and corporate cultural mechanisms (Al-Najem et al., 2013).

Not only has literature highlighted a lack of knowledge and difficulties in implementing lean in the Middle Eastern and Gulf countries, but also and increasing concern of LI in small and medium enterprises (SMEs) (Al-Najem, 2014). A reason for the difficulties in implementing lean is a lack of understanding of Toyota's corporate culture and how it facilitated the success of lean within the organisation (Achanga et al., 2006). According to $\mathrm{Xu}$ et al. (2013), SMEs are a vital part of a nation's economic prosperity and in some Middle Eastern countries SMEs get little attention or support in comparison to the larger oil and gas companies. According to Al-Najem et al. (2013), authors suggest that research on implementing lean in SMEs in Kuwait is non-existent. According Calabrò and Mussolino (2013), SMEs face different challenges in business and in internationalisation due to the nature of numerous informalities which permeate numerous areas of the business such as board members relationships which are heavily based on trust, informal governance mechanisms, and non-economic goals driven by the family in family owned businesses. This informal nature has been attributed to impact on SMEs export intensity (Calabrò and Mussolino, 2013). Calabrò and Mussolino (2013) studied LI in SMEs in manufacturing in general suggest, a greater emphasis on in house elements which are less financial in investment are key to the success of LI in SMEs. In addition to this, Rose et al. (2010) suggest that SMEs should implement lean gradually starting with aspects which are the easiest to implement and the most cost effective. While the research by Rose et al. (2010) is particularly useful to this study, its focus is on lean best practices for SMEs and OC aspects are not addressed. According to MENA (2004), Arabic countries have their own specific attributes and most companies are SMEs with an OC that strongly reflects their nature as a 'family' business. MENA (2004) highlights the need for universalising business principles and responsibilities of boards of directors and governance if Arabic SMEs are to be able to internationalise. According to 
Ahmed et al. (1999), Arab organisations can benefit significantly by implementing quality initiatives to address their weakness and make them more competitive on an international scale. However, there is a real gap in research pertaining the influence of OC in implementing lean among SMEs in Arabic countries and Saudi Arabia.

\section{Methodology}

Qualitative research is confirmed to be useful for uncovering such insider views (Corbin and Strauss, 1990). The research will be based on qualitative and grounded theory inside action research with and an inductive approach. Action research tends to be used for prompting conscious change within a somewhat controlled environment (Collis and Hussey, 2013). In this approach, the participants and the researcher collaborate on a problem to find a solution (Coghlan and Brannick, 2014). This is an inquiry mode generally utilised to help solve organisational issues by dealing with those experiencing the problems (Ibrahim, 2013). Some main weaknesses associated with action research is the assumption that the behaviour of a person is only able to be changed by testing them and moreover, it tends to require set timelines and is usually expensive to conduct over the full research period (Fisher, 2007). Grounded theory is a research methodology which aims to create a theory from data which has been systematically researched and analysed (Strauss, 1987). This methodology was founded originally by Glaser and Strauss (1967). According to Golden-Biddle and Locke (2007), grounded theory has been the most vastly utilised qualitative methodology in social science research. Its popularity can be attributed to; firstly, its suitability for developing new theory or new insights form old theory. Secondly, it generates theory which stems from what the research participants consider important. Finally, it is able to expose micro-management processes in complex situations and environments (Locke, 2001). Goulding (1998) suggests grounded theory is particularly useful for making new discoveries thus its usefulness for theory generation. Furthermore, Locke (2001) and Goulding (2005) also consider grounded theory as useful where there is a clear lack of integrated theory in an area of literature. The main feature of this approach is to develop categories which highlight the data and develop the categories to create a framework (Silverman, 2006). Due to the nature of the topic requiring the exploration of culture it is beneficial to utilise qualitative research. An inductive approach enables the researcher to become fully engaged within the research environment thus improving the understanding of the culture being studied, facilitating a more insider's view of the culture (Walker and Myrick, 2006). Furthermore, it is important to note that most methodologies require extensive literature reviews to inform the research and identify the research question as most research methodology is conducted with a deductive approach (Dick, 2006). In contrast, grounded theory being inductive ends with a theory as opposed to beginning with a hypothesis and instead is used as a method for reviewing literature (Trochim and Donnelly, 2001). Hence, why research questions and hypotheses are made redundant in grounded theory so, literature is generally used as a comparator (Dick, 2006).

From the interviews, all the results will constantly be compared to the information found in the literature review. During the coding, the process becomes more structures in order to validate relationships within the data and finally during themes, the agenda becomes more deliberate in order integrate the findings within the categories to achieve 
data saturation (Strauss and Corbin, 2008). Data saturation refers to the stage when the data collected in the research is now redundant (Bogdan and Biklen, 2007). This is necessary to ensure enough data has been collected to reflect the perspectives of the research participants (Kolb, 2012).

Data analysis in qualitative research deals with words, and the meanings implied by them (Miles and Huberman, 1994). The analysis of the information gathered is done by discovering categories and their interrelationships, simultaneous and concurrent data and alongside constant comparison methods. The program utilised for this is NVIVO software for coding. The tool generally employed to study culture consist of; semi structured or in-depth interviews, observation and focus groups. Focus groups are another tool for revealing cultural assumptions and according to Schein (1985) "because the group provides the stimulus to bring out what is ordinarily hidden.” The main premise of the focus group for this research is that the participants will name the categories and provide the data for under each category thus it will fully reflect the ideas and perceptions of what is important to the employees. Interviews are open ended questions gaining indepth responses about people's experiences, perceptions, opinions and feelings and knowledge (Taylor, 2005). In depth interviews/unstructured interviews are often utilised to help expose culturally-based values (Patton, 2014). The key here is, the researcher should not introduce cultural values, but instead using open ended questions and the insider's language, they evoke responses revealing the aspects of everyday life in that cultural setting (Creswell, 2013). It is important for the researcher to be conscious of their own biases and influences in the information gathering process (Patton, 2014). It is important however, for the assisting analysts to also have an understanding of the research setting from an insider's perspective (Sackmann, 1991). For this research semi structures interviews, will also be utilised. The advantage with semi structures interviews is that it ensures certain topics are covered making it more comparable and reliable qualitative information (Patton, 2014).

To obtain a better understanding of the nature of (OCs) within SMEs in manufacturing industry this study will focus on three main criteria; firstly, to expose the implied components of culture from an insider's perspective. Secondly, to be mindful of structural aspects of the culture for example sub cultures (Babbie, 2015). Thirdly, to facilitate comparisons to be made among individuals and research settings (Birkinshaw et al., 2011). The use of this criteria has enabled an issue focused interview style which is founded upon the phenomenological orientation leading to successive comparison (Birkinshaw et al., 2011). In addition; these focus groups and observations are utilised to provide triangulation of results. Issue focussed investigation allows for the fulfilment of the above criteria. Due to the nature of culture being omnipresent, this makes it difficult for people to often reflect and describe when asked a question about it directly (Dey, 1999). Therefore, in order to draw this out it often requires a response to stimulus requiring respondents to interpret something, which is naturally done according to their own cultural basis as opposed to that of the researcher (Sackmann, 1991). Furthermore, and issue focus investigation is particularly suitable because, by presenting them with a stimulus with a specific context, the respondents then tend to access the same library of knowledge already existing in their minds (Sackmann, 1991). This helps to uncover the framework about a specific issue. This then enables comparisons of the interpretations to uncover individual opinions from cultural beliefs which are common among the group, (Willis et al., 2007). Issue focussed investigation needs to be conducted cleverly to ensure the participants do not realise the issue is under investigation (Sackmann, 1991). 
The phenomenological orientation has its focus on the insider's perspective and their beliefs and concepts, ideas of the (OC) and life within it. It places emphasis on the insider's view of what is considered important and relevant within that setting (Goulding, 2005). The researcher will put aside their own assumption so these do not interfere or influence the respondent's answers. The emphasis is to allow the respondents to gradually unravel their own experiences. In order for the researcher to avoid making judgments based on their own beliefs, these should firstly be made clear (Annells, 1996). The interview procedure in phenomenological orientation is close in style to an in depth or intense interview. This usually consists of a longer introduction and a period of becoming better acquainted. This also gives the researcher the chance to gently introduce the subject of the discussion (Srubar, 1998). The aspects which are brought up by the respondent are the points which are then delved into with more detail. In doing so, the researcher is better able to explore together with the respondent and identify the cognitive frameworks which come up (Bryant, 2009). This process of an established dialogue also enables the researcher to check they have understood the respondent's point of view correctly. This can be done by the researcher mentally answering the question in their head before the respondent has a chance to check their own accuracy (Goulding, 2005). This type of research requires not only flexibility but a rapport to have been well established between the researcher and the respondent because for in depth issues to come to light the interviewee needs to feel comfortable, safe and that a mutual trust exists (Goulding, 2005).

There are some advantages to employing both an issue focused investigation and a phenomenological orientation. The latter is much unstructured and broad however, the issue focus investigation works to narrow the scope giving more structure to the process. Furthermore, the researcher takes their cue from the respondents as to the most important aspects to be further explored (Sackmann, 1991). The respondents were asking to mention the aspects of lean they considered most important in their organisation (for example). They were also asked to explain why these were the most important. This enables the researcher to cross compare the responses of the individuals increasing reliability. In the phenomenological phase, the researcher ensures all aspects of the factors brought up by the respondents are investigated (Bryant, 2009). Therefore, this particular approach by Sackmann (1991) has been selected for this research. In this case the questions been asked are issues focussed in accordance with Sackman's (1991) approach: tell me about an example you have seen implementation of lean work well?, tell me about situation of LI has not work well?. Therefore, a combination of issues and phenomenological approach proposed by Sackmann (2006) is being utilised due to its suitability to analysing (OC). In addition to this the grounded theory method of Strauss and Corbin (1994) will be adopted. This is an inquiry mode generally utilised to help solve organisational issues by dealing with those experiencing the problems (Ibrahim, 2013). The data sample for the participating companies in this main study has been provided. The target organisations which the researcher conduct were steel, electric, oil, paper, packaging and construction industries, which are in Saudi Arabia. The main study was conducted between November 2016 and February 2017. The sampling has been selected based on the experiences of the employees of the organisations mentioned. 


\section{Result}

\subsection{Semi-structured interview}

The researcher conducted twenty-nine semi-structured interviews with all companies, where they currently face barriers to implement lean (Karim et al., 2011). The sampling has been selected based on their experiences. The participants ranged in terms of their position in the organisations. Therefore, the sampling method refers more to events and incidents as opposed to participants (Corbin and Strauss, 1990). Having conducted the main study using semi-structured interviews, codes were developed, these can be seen in the Table 1.

Table 1 Organisational culture aspects which influences LI

\begin{tabular}{|c|c|c|c|c|c|c|c|}
\hline \multicolumn{8}{|c|}{ Aspects of organisational culture } \\
\hline 1 & Job description & 2 & $\begin{array}{l}\text { Health and } \\
\text { safety } \\
\text { awareness }\end{array}$ & 3 & $\begin{array}{l}\text { Quality of } \\
\text { inspections }\end{array}$ & 4 & $\begin{array}{l}\text { Professional } \\
\text { training in lean }\end{array}$ \\
\hline 5 & $\begin{array}{l}\text { Many decision } \\
\text { makers }\end{array}$ & 6 & $\begin{array}{l}\text { Role of the } \\
\text { family }\end{array}$ & 7 & Knowledge share & 8 & Poor planning \\
\hline 9 & Short-term focus & 10 & $\begin{array}{l}\text { Motivation and } \\
\text { reward system }\end{array}$ & 11 & $\begin{array}{l}\text { Promotional } \\
\text { opportunities }\end{array}$ & 12 & $\begin{array}{l}\text { Recruitment } \\
\text { process }\end{array}$ \\
\hline 13 & $\begin{array}{l}\text { Workshop tools } \\
\text { and guidance }\end{array}$ & 14 & $\begin{array}{l}\text { Delay of } \\
\text { processing } \\
\text { staff requests }\end{array}$ & 15 & $\begin{array}{l}\text { Resistance to } \\
\text { change }\end{array}$ & 16 & $\begin{array}{l}\text { Ineffective } \\
\text { multi-tasking }\end{array}$ \\
\hline 17 & Feedback system & 18 & $\begin{array}{l}\text { Improper } \\
\text { prioritisation } \\
\text { of tasks }\end{array}$ & 19 & $\begin{array}{l}\text { Performance } \\
\text { indicators }\end{array}$ & 20 & $\begin{array}{l}\text { Contingency } \\
\text { planning }\end{array}$ \\
\hline 21 & $\begin{array}{l}\text { Teamwork and } \\
\text { leadership } \\
\text { attitudes }\end{array}$ & 22 & Job security & 23 & $\begin{array}{l}\text { Aggression on } \\
\text { the shop floor }\end{array}$ & 24 & $\begin{array}{l}\text { Productivity } \\
\text { monitoring }\end{array}$ \\
\hline 25 & $\begin{array}{l}\text { Cooperation and } \\
\text { mutual trust } \\
\text { between } \\
\text { management } \\
\text { employees }\end{array}$ & 26 & $\begin{array}{l}\text { Bureaucratic } \\
\text { management } \\
\text { style }\end{array}$ & 27 & $\begin{array}{l}\text { Innovation } \\
\text { management }\end{array}$ & 28 & $\begin{array}{l}\text { Loyalty of the } \\
\text { staff }\end{array}$ \\
\hline 29 & $\begin{array}{l}\text { Research and } \\
\text { development } \\
\text { (R\&D }\end{array}$ & 30 & $\begin{array}{l}\text { Emphasis over } \\
\text { individual } \\
\text { contribution }\end{array}$ & 31 & $\begin{array}{l}\text { System of } \\
\text { decision-making }\end{array}$ & 32 & $\begin{array}{l}\text { Socialisation of } \\
\text { the staff }\end{array}$ \\
\hline 33 & $\begin{array}{l}\text { Emotional } \\
\text { intelligence of } \\
\text { managers }\end{array}$ & 34 & $\begin{array}{l}\text { Workload } \\
\text { pressure }\end{array}$ & 35 & $\begin{array}{l}\text { Ambiguity of } \\
\text { policies }\end{array}$ & 36 & $\begin{array}{l}\text { Obligatory } \\
\text { work }\end{array}$ \\
\hline 37 & $\begin{array}{l}\text { Identification of } \\
\text { resources }\end{array}$ & & & & & & \\
\hline
\end{tabular}

\subsection{Focus group}

The researcher conducted two focus groups after concluding 29 semi-structured interviews. The sampling for both focus groups have been selected based on the candidates' experience. Both focus groups had the same participants. The participants 
engaged in a process to review the results from the semi-structured interview, with the objective of making suggestions to grouped the aspects to high level theme. The participants involved in the focus group discussions included two CEOs, production engineers, mechanical engineers, chief engineers and two workers. The dates and times were pre-arranged based on the availability of the candidates and interviews were conducted in a private office within a hotel. The purpose for this focus group One is to help refine and further develop the findings of OC aspects from semi-structured interviews. This allowed participants to express their opinions more easily by discussing real examples, thus allowing for a thorough, detailed and intensive data set. The observations were noted by the researcher scrupulously. To conclude, participants reviewed the results of the output from the stage one data collection (interview). Thus, bringing about 39 codes and providing definition for each code. Having conducted the prime study of semi-structured interviews, the following aspects were developed, these can be seen in the Table 2. The purpose for the focus group Two is to aggregate the cultural aspects developed into higher level themes. The researcher presented the output results from the first focus group to allow the participants to familiarise themselves with the subject matter. Refreshments and ample breaks were provided during focus group. The participants starting to group the codes in seven themes, and provided definition for each category. Table 3 provides an overview of themes. Seven themes have been identified by the participants, each theme contain aspects. Each theme has suggested definition by participants shown in Table 3.

Table 2 Aspects of OC influencing LI

\begin{tabular}{|c|c|c|}
\hline No. & $\begin{array}{l}\text { Aspects of } \\
\text { organisational } \\
\text { culture }\end{array}$ & Participants' representation of aspects \\
\hline 1 & Job description & $\begin{array}{l}\text { The detail of job activities not clearly established among working } \\
\text { staff. These unclear procedural activities directly lead to confusion } \\
\text { regarding the correct steps which need to be taken. }\end{array}$ \\
\hline 2 & $\begin{array}{l}\text { Health and safety } \\
\text { awareness }\end{array}$ & $\begin{array}{l}\text { Discusses the methods the health and safety procedures of the } \\
\text { organisation. A lack of awareness of health and safety policies } \\
\text { within the workplace has led to poor working conditions and } \\
\text { increased the risk of health hazards. }\end{array}$ \\
\hline 3 & Quality inspection & $\begin{array}{l}\text { The quality of inspections has not been standardised and hence } \\
\text { procedural errors occurred leading to sporadic delays in } \\
\text { implementing lean. }\end{array}$ \\
\hline 4 & $\begin{array}{l}\text { Professional } \\
\text { training in lean }\end{array}$ & $\begin{array}{l}\text { Employees were unaware of the lean philosophy, what it aims to } \\
\text { achieve and ultimately how this will be achieved. There is a need to } \\
\text { facilitate a professional lean Training in terms of } \\
\text { workshops/seminars for all staff to realise the advantages and } \\
\text { efficiencies of lean. }\end{array}$ \\
\hline 5 & $\begin{array}{l}\text { Many decision } \\
\text { makers }\end{array}$ & $\begin{array}{l}\text { In the presence of a high number of stakeholders, there is a need to } \\
\text { follow protocols. A high number of tenured employees in middle } \\
\text { and senior management roles made decisions based on their } \\
\text { experience, rather than following a company- wide decision-making } \\
\text { policy. This resulted in confusion among several teams and potential } \\
\text { errors within the organisation. }\end{array}$ \\
\hline
\end{tabular}


Table 2 Aspects of OC influencing LI (continued)

\begin{tabular}{|c|c|c|}
\hline No. & $\begin{array}{l}\text { Aspects of } \\
\text { organisational } \\
\text { culture }\end{array}$ & Participants' representation of aspects \\
\hline 6 & Role of family & $\begin{array}{l}\text { The role of family seemed to influence the work process. When } \\
\text { family members were not involved in the work process, staff could } \\
\text { make organised decisions. }\end{array}$ \\
\hline 7 & Knowledge share & $\begin{array}{l}\text { Decision making by senior management has remained } \\
\text { unquestionable and neither has there been a culture of dialogue } \\
\text { between management and employees. This resulted in knowledge } \\
\text { gap and division among working staff. }\end{array}$ \\
\hline 8 & Poor planning & $\begin{array}{l}\text { The organisation regularly wasted too much time in dealing with } \\
\text { implementation problems which could have been foreseen and } \\
\text { eliminated with the use of proper planning and past experiences. }\end{array}$ \\
\hline 9 & Short-term focus & $\begin{array}{l}\text { Senior management focused their efforts on the short-term } \\
\text { accomplishments (weeks/months) as opposed to long-term strategic } \\
\text { goals. This has a direct implication for sustainable ROI (Return on } \\
\text { Investment). }\end{array}$ \\
\hline 10 & $\begin{array}{l}\text { Motivation and } \\
\text { reward system }\end{array}$ & $\begin{array}{l}\text { The organisation does not have rewards-based recognition system to } \\
\text { encourage the employees over performance. The presence of such a } \\
\text { rewarding culture in the organisation would motivate the employees } \\
\text { which directly would enhance their productivity. }\end{array}$ \\
\hline 11 & $\begin{array}{l}\text { Promotional } \\
\text { opportunities }\end{array}$ & $\begin{array}{l}\text { Employees are not given the opportunity to be promoted to } \\
\text { middle/senior management positions despite their achievements, } \\
\text { high performances or even long tenured years of service. }\end{array}$ \\
\hline 12 & $\begin{array}{l}\text { Recruitment } \\
\text { process }\end{array}$ & $\begin{array}{l}\text { The employees within the organisation were often unskilled and } \\
\text { unexperienced in the work they were recruited for. This required } \\
\text { additional training before they could be placed for production. }\end{array}$ \\
\hline 13 & $\begin{array}{l}\text { workshop tools } \\
\text { and guidance }\end{array}$ & $\begin{array}{l}\text { The organisation does not provide its employees with organisational } \\
\text { tools such as handbooks which can assist in their day to day work } \\
\text { procedures and task fulfilments. }\end{array}$ \\
\hline 14 & $\begin{array}{l}\text { Delay of staff's } \\
\text { requests }\end{array}$ & $\begin{array}{l}\text { Due to the high number of management tiers, it takes a long time } \\
\text { before requests can be accepted/rejected. }\end{array}$ \\
\hline 15 & $\begin{array}{l}\text { Resistance of } \\
\text { change }\end{array}$ & $\begin{array}{l}\text { A behaviour taken by individuals or groups when they observe that } \\
\text { a change is happen and perceived as a threatening to them. }\end{array}$ \\
\hline 16 & $\begin{array}{l}\text { Ineffective } \\
\text { multi-tasking }\end{array}$ & $\begin{array}{l}\text { Employees within the organisation are given multiple roles and } \\
\text { tasks, which causes confusion and does not allow them to finish } \\
\text { their tasks effectively. }\end{array}$ \\
\hline 17 & Feedback system & $\begin{array}{l}\text { Feedback or evaluation systems are non-existent. If these were } \\
\text { available, it would enable management to understand problems } \\
\text { raised by employees. Employees are unable to understand the } \\
\text { impact of decisions made by senior management. }\end{array}$ \\
\hline 18 & $\begin{array}{l}\text { Improper } \\
\text { prioritisation of } \\
\text { tasks }\end{array}$ & $\begin{array}{l}\text { The sequence of tasks which needs to be completed is unclear and } \\
\text { disorderly. Due to this and other organisational changes employees } \\
\text { were unable to achieve the targets set. }\end{array}$ \\
\hline 19 & $\begin{array}{l}\text { Performance } \\
\text { indicators }\end{array}$ & $\begin{array}{l}\text { There is no system of recording employee performance, therefore } \\
\text { the organisation is unable to understand and comprehend employee } \\
\text { productivity. }\end{array}$ \\
\hline
\end{tabular}


Table 2 Aspects of OC influencing LI (continued)

\begin{tabular}{|c|c|c|}
\hline No. & $\begin{array}{l}\text { Aspects of } \\
\text { organisational } \\
\text { culture }\end{array}$ & Participants' representation of aspects \\
\hline 20 & $\begin{array}{l}\text { Contingency } \\
\text { planning }\end{array}$ & $\begin{array}{l}\text { The organisation does not have a contingency plan which could } \\
\text { guide them in case of an emergency and thus resume operations. }\end{array}$ \\
\hline 21 & $\begin{array}{l}\text { Teamwork and } \\
\text { leadership attitude }\end{array}$ & $\begin{array}{l}\text { The different functions within the organisation have their own } \\
\text { individual plans, without communicating their plan with other } \\
\text { departments, rather than working as an effective team. }\end{array}$ \\
\hline 22 & Job security & $\begin{array}{l}\text { There is no guarantee of job security despite an employee's best } \\
\text { efforts. }\end{array}$ \\
\hline 23 & $\begin{array}{l}\text { Aggression to the } \\
\text { shop floor }\end{array}$ & $\begin{array}{l}\text { Due to the hierarchical nature of the organisation, senior } \\
\text { management are aggressive in directing their lower ranking } \\
\text { employees. }\end{array}$ \\
\hline 24 & $\begin{array}{l}\text { Productivity } \\
\text { monitoring }\end{array}$ & $\begin{array}{l}\text { Productivity was not measured other than recorded daily tasks and } \\
\text { ability to meet deadlines. The key reason for poor productivity was } \\
\text { related to lack of motivation by the employees. }\end{array}$ \\
\hline 25 & $\begin{array}{l}\text { Cooperation and } \\
\text { mutual trust } \\
\text { between } \\
\text { management } \\
\text { employees }\end{array}$ & $\begin{array}{l}\text { Lack of reputability such as not taking ownership of tasks and not } \\
\text { executing within allocated time prevailed. This lead to working } \\
\text { inefficiencies. Employees do not feel safe to share their inner } \\
\text { believes or feeling with senior management as they fear they will } \\
\text { receive negative feedback. Senior management are unreceptive to } \\
\text { ideas/improvements which have been put forward by junior } \\
\text { employees. }\end{array}$ \\
\hline 26 & $\begin{array}{l}\text { Bureaucratic } \\
\text { management style }\end{array}$ & $\begin{array}{l}\text { Management style followed a rigid structure in dealing with } \\
\text { employees by not accounting the personal factors relative to } \\
\text { individual employees. Rather, a rigid structure was applied to all } \\
\text { working staff regardless of individual circumstances. }\end{array}$ \\
\hline 27 & $\begin{array}{l}\text { Innovation } \\
\text { management }\end{array}$ & $\begin{array}{l}\text { The top management has not held any initiatives to develop } \\
\text { innovation nor thought to implement any in the road map. This may } \\
\text { lead to critical issues for future sustenance. }\end{array}$ \\
\hline 28 & $\begin{array}{l}\text { Loyalty of the } \\
\text { staff }\end{array}$ & $\begin{array}{l}\text { Most of the employees displayed no sign of loyalty to the } \\
\text { organisations. They were primarily driven by the work and pay } \\
\text { system which was mechanical. }\end{array}$ \\
\hline 29 & $\begin{array}{l}\text { Research and } \\
\text { development } \\
(\mathrm{R} \& D)\end{array}$ & $\begin{array}{l}\text { There has been neither support nor interest from the top } \\
\text { management in investing into R\&D activities that lead to a } \\
\text { sustainable future of the organisation. The organisation carried a } \\
\text { unidimensional strategy. }\end{array}$ \\
\hline 30 & $\begin{array}{l}\text { Emphasis over } \\
\text { individual } \\
\text { contribution }\end{array}$ & $\begin{array}{l}\text { Focus on individual contribution was seen to be lacking and a result } \\
\text { key factors such as capabilities, lean and development, and } \\
\text { productivity were ignored. Supporting the employee to increase the } \\
\text { capability of knowledge. }\end{array}$ \\
\hline 31 & $\begin{array}{l}\text { System of } \\
\text { decision-making }\end{array}$ & $\begin{array}{l}\text { Design a management system to produce orders and decisions to } \\
\text { identify, solve problems and make decisions. }\end{array}$ \\
\hline 32 & $\begin{array}{l}\text { Socialisation of } \\
\text { the staff }\end{array}$ & $\begin{array}{l}\text { Many employees lacked social knowledge and inter-personal skills } \\
\text { which are required to foster a healthy professional environment. } \\
\text { Most of the employees were only concerned with work and pay. }\end{array}$ \\
\hline
\end{tabular}


Table 2 Aspects of OC influencing LI (continued)

\begin{tabular}{|c|c|c|c|c|}
\hline No. & \multicolumn{2}{|c|}{$\begin{array}{l}\text { Aspects of } \\
\text { organisational } \\
\text { culture }\end{array}$} & \multicolumn{2}{|c|}{ Participants' representation of aspects } \\
\hline 33 & \multicolumn{2}{|c|}{$\begin{array}{l}\text { Emotional } \\
\text { intelligence of } \\
\text { managers }\end{array}$} & \multicolumn{2}{|c|}{$\begin{array}{l}\text { How to monitor other people's emotion, thinking and behaviour. It } \\
\text { is the ability to recognise and deal with other people emotion } \\
\text { effectively, it is basically putting the self in the shoes of others. } \\
\text { Understanding of the context and having awareness of others. Lack } \\
\text { of emotional support from managers was prevalent. In order to } \\
\text { understand emotions, thought processes and behaviour of staff, it is } \\
\text { important for managers to have the ability to recognise and deal } \\
\text { with other people effectively. }\end{array}$} \\
\hline 34 & \multicolumn{2}{|l|}{$\begin{array}{l}\text { Workload } \\
\text { pressure }\end{array}$} & \multicolumn{2}{|c|}{$\begin{array}{l}\text { Daily routine of same kind of work along with orders to finish } \\
\text { within deadlines from supervisors has resulted in creating additional } \\
\text { pressure for the employees. This lead to pileup of stress at work. } \\
\text { This could be eased with the help of recreational activities. }\end{array}$} \\
\hline 35 & \multicolumn{2}{|c|}{$\begin{array}{l}\text { Ambiguity of } \\
\text { policies }\end{array}$} & \multicolumn{2}{|c|}{$\begin{array}{l}\text { Reliable information about the performance, governance, value and } \\
\text { risks of all information related to the employee. }\end{array}$} \\
\hline 36 & \multicolumn{2}{|c|}{ Obligatory work } & \multicolumn{2}{|c|}{$\begin{array}{l}\text { The environment that prevailed in the organisations was that of an } \\
\text { enforceable culture rather than a proactive culture. Instead of } \\
\text { constructive criticism and supportive directions, employees were } \\
\text { often commanded and reminded of their duties. }\end{array}$} \\
\hline 37 & \multicolumn{2}{|c|}{$\begin{array}{l}\text { Identification of } \\
\text { resources }\end{array}$} & \multicolumn{2}{|c|}{$\begin{array}{l}\text { Diagnose and analyse resources required and provide the right } \\
\text { information related to work. }\end{array}$} \\
\hline \multicolumn{5}{|c|}{ Table 3} \\
\hline \multicolumn{2}{|c|}{$\begin{array}{l}\text { Higher level } \\
\text { theme }\end{array}$} & $\begin{array}{l}\text { Aspects } \\
\text { code }\end{array}$ & $\begin{array}{l}\text { Aspects grouped } \\
\text { together into higher } \\
\text { level }\end{array}$ & $\begin{array}{l}\text { Participants statements used to } \\
\text { describe the higher-level theme }\end{array}$ \\
\hline \multirow{5}{*}{\multicolumn{2}{|c|}{$\begin{array}{l}\text { Communication } \\
\text { and interaction in } \\
\text { the organisation }\end{array}$}} & 5 & $\begin{array}{l}\text { Many decision } \\
\text { makers }\end{array}$ & \multirow{5}{*}{$\begin{array}{l}\text { Convoy your massage to other personal } \\
\text { or a group. Thus, the employees know } \\
\text { exactly what is important, who is } \\
\text { supposed to do what and when. } \\
\text { Communication among the staff climate } \\
\text { formal and informal information flows } \\
\text { in time for inquiry and reflection use of } \\
\text { humour and many other languages. }\end{array}$} \\
\hline & & 7 & Knowledge share & \\
\hline & & 14 & $\begin{array}{l}\text { Delay of staff's } \\
\text { requests }\end{array}$ & \\
\hline & & 16 & Ineffective & \\
\hline & & 34 & Workload pressure & \\
\hline \multirow{6}{*}{\multicolumn{2}{|c|}{$\begin{array}{l}\text { Organisation's } \\
\text { strategy and } \\
\text { vision }\end{array}$}} & 8 & Poor planning & \multirow{6}{*}{$\begin{array}{l}\text { An essential factor which influences } \\
\text { different control system configuration } \\
\text { and operational environment change. } \\
\text { Identify tactics and roadmap to achieve } \\
\text { the mission of the organisation. } \\
\text { Generate an objective to align the } \\
\text { managerial practices process with their } \\
\text { strategies priorities to improve their } \\
\text { performance, system of decision } \\
\text { making and to apply in the organisation. }\end{array}$} \\
\hline & & 9 & Short-term focus & \\
\hline & & 18 & $\begin{array}{c}\text { Improper } \\
\text { Prioritisation of tasks }\end{array}$ & \\
\hline & & 35 & $\begin{array}{l}\text { Ambiguity of } \\
\text { policies }\end{array}$ & \\
\hline & & 31 & $\begin{array}{c}\text { System of } \\
\text { decision-making }\end{array}$ & \\
\hline & & 6 & Role of family & \\
\hline
\end{tabular}


Table 3 Themes developed (continued)

\begin{tabular}{|c|c|c|c|}
\hline $\begin{array}{l}\text { Higher level } \\
\text { theme }\end{array}$ & $\begin{array}{l}\text { Aspects } \\
\text { code }\end{array}$ & $\begin{array}{c}\text { Aspects grouped } \\
\text { together into higher } \\
\text { level }\end{array}$ & $\begin{array}{l}\text { Participants statements used to } \\
\text { describe the higher-level theme }\end{array}$ \\
\hline \multirow[t]{2}{*}{$\begin{array}{l}\text { Organisation's } \\
\text { infrastructure of } \\
\text { the workshop }\end{array}$} & 2 & $\begin{array}{l}\text { Health and safety } \\
\text { awareness }\end{array}$ & $\begin{array}{l}\text { This theme refers to the structure of the } \\
\text { organisation around the employee. } \\
\text { Easily for employees to move with } \\
\text { security around within the } \\
\text { confinements of their workplace. Poor } \\
\text { Infrastructure planning was evident } \\
\text { from the layout of the workshop. } \\
\text { Ineffective planning resulted in } \\
\text { redundant activities and procedures } \\
\text { indicating a re-design of workshop } \\
\text { layout to complement lean. }\end{array}$ \\
\hline & 13 & $\begin{array}{l}\text { Workshop tools and } \\
\text { guidance }\end{array}$ & $\begin{array}{l}\text { This theme refers to the structure of the } \\
\text { organisation around the employee. } \\
\text { Easily for employees to move with } \\
\text { security around within the } \\
\text { confinements of their workplace. Poor } \\
\text { infrastructure planning was evident } \\
\text { from the layout of the workshop. } \\
\text { Ineffective planning resulted in } \\
\text { redundant activities and procedures } \\
\text { indicating a re-design of workshop } \\
\text { layout to complement lean. }\end{array}$ \\
\hline \multirow{4}{*}{$\begin{array}{l}\text { Quality risk } \\
\text { management }\end{array}$} & 3 & Quality inspection & \multirow{4}{*}{$\begin{array}{l}\text { A group of business process, } \\
\text { technology capabilities and operation } \\
\text { environment to create a collaborative } \\
\text { program to identifying mitigating } \\
\text { product, quantifying, operational risks } \\
\text { that can be impact quality. }\end{array}$} \\
\hline & 19 & $\begin{array}{l}\text { Performance } \\
\text { indicators }\end{array}$ & \\
\hline & 20 & $\begin{array}{l}\text { Contingency } \\
\text { planning }\end{array}$ & \\
\hline & 29 & $\begin{array}{l}\text { Research and } \\
\text { development (R\&D) }\end{array}$ & \\
\hline \multirow[t]{6}{*}{ Human resource } & 1 & Job description & \multirow{6}{*}{$\begin{array}{l}\text { This they refer to the employees' } \\
\text { issues. It is a set of role related to the } \\
\text { employee, describing their duty. } \\
\text { Determine the needs of the employee } \\
\text { and recruit best employees. Dealing } \\
\text { with performance and trouble issues. } \\
\text { Pushing the employees to the best in } \\
\text { their job. }\end{array}$} \\
\hline & 10 & $\begin{array}{l}\text { Motivation and } \\
\text { reward system }\end{array}$ & \\
\hline & 11 & $\begin{array}{l}\text { Promotional } \\
\text { opportunities }\end{array}$ & \\
\hline & 12 & Recruitment process & \\
\hline & 22 & Job security & \\
\hline & 17 & Feedback system & \\
\hline \multirow{5}{*}{$\begin{array}{l}\text { Change } \\
\text { management and } \\
\text { behaviour } \\
\text { patterns }\end{array}$} & 21 & $\begin{array}{l}\text { Teamwork and } \\
\text { leadership attitude }\end{array}$ & \multirow{5}{*}{$\begin{array}{l}\text { Approach to transitioning group, team } \\
\text { and organisation using tactics to } \\
\text { re-direct the use of organisation system } \\
\text { process, resources, organisation } \\
\text { environment, the reaction of the } \\
\text { employees or any other method in the } \\
\text { operation that reshape effectively the } \\
\text { organisation. }\end{array}$} \\
\hline & 23 & $\begin{array}{l}\text { Aggression to the } \\
\text { shop floor }\end{array}$ & \\
\hline & 36 & Obligatory work & \\
\hline & 26 & $\begin{array}{l}\text { Bureaucratic } \\
\text { management }\end{array}$ & \\
\hline & 15 & Resistance to change & \\
\hline
\end{tabular}


Table 3 Themes developed (continued)

\begin{tabular}{|c|c|c|c|}
\hline $\begin{array}{l}\text { Higher level } \\
\text { theme }\end{array}$ & $\begin{array}{l}\text { Aspects } \\
\text { code }\end{array}$ & $\begin{array}{l}\text { Aspects grouped } \\
\text { together into higher } \\
\text { level }\end{array}$ & $\begin{array}{c}\text { Participants statements used to describe } \\
\text { the higher-level theme }\end{array}$ \\
\hline \multirow[t]{9}{*}{$\begin{array}{l}\text { Sustain } \\
\text { continuous } \\
\text { improvement }\end{array}$} & 25 & $\begin{array}{c}\text { Cooperation and } \\
\text { mutual trust between } \\
\text { employees }\end{array}$ & \multirow{9}{*}{$\begin{array}{l}\text { Keep going or to keep up to improve } \\
\text { the employee and process performance } \\
\text { to be continually monitored. Focusing } \\
\text { to increase the capabilities, efficiency } \\
\text { and the effectiveness to achieve its } \\
\text { objectives. Identify the opportunity for } \\
\text { streaming work. Many employees in the } \\
\text { top management were aware of the } \\
\text { prevailing gap in the organisation at } \\
\text { various functions of engagements such } \\
\text { as operations, human relations, and } \\
\text { productions. }\end{array}$} \\
\hline & 28 & Loyalty of the staff & \\
\hline & 33 & $\begin{array}{c}\text { Emotional } \\
\text { intelligence of } \\
\text { managers }\end{array}$ & \\
\hline & 30 & $\begin{array}{l}\text { Emphasis on the } \\
\text { Individual } \\
\text { contribution }\end{array}$ & \\
\hline & 27 & $\begin{array}{l}\text { Innovation } \\
\text { management }\end{array}$ & \\
\hline & 37 & $\begin{array}{l}\text { Identification of } \\
\text { resources }\end{array}$ & \\
\hline & 32 & $\begin{array}{l}\text { Socialisation of the } \\
\text { staff }\end{array}$ & \\
\hline & 4 & $\begin{array}{l}\text { Professional training } \\
\text { in lean }\end{array}$ & \\
\hline & 24 & $\begin{array}{l}\text { Productivity } \\
\text { monitoring }\end{array}$ & \\
\hline
\end{tabular}

\section{Validation}

All these aspects have been reviewed and discussed by participants through Focus Group One. In addition, in this paper the inter-rate reliability took place in the early stage of the analysis process. The procedure requires having two or more judges independently to determine the significance, degree and sample stability of their agreement (Rashid, 2010). Gwet (2002) suggests that evaluation of the agreement between two or more ratters is commonly used in social, medical and behavioural sciences, the result of using inter-rate reliability presented in Table 4. Moreover, Guba and Lincoln, (1994) propose a further method for evaluating qualitative research which is based upon four criteria see Table 5 and has been applied top this paper.

Table 4 Inter-rate reliability result

\begin{tabular}{llcccc}
\hline No. & Interview & Ratter 1 & Ratter 2 & Kappa & $\%$ \\
\hline 1 & Interview no. 7 & 33 & 31 & 0.72 & $94 \%$ \\
2 & Interview no. 8 & 30 & 29 & 0.78 & $97 \%$ \\
3 & Interview no. 17 & 46 & 45 & 0.79 & $98 \%$ \\
4 & Interview no. 18 & 49 & 49 & 1.00 & $100 \%$ \\
5 & Interview no. 25 & 39 & 38 & 0.79 & $97 \%$ \\
6 & Interview no. 30 & 43 & 42 & 0.79 & $98 \%$ \\
\hline
\end{tabular}


Table 4 Inter-rate reliability result (continued)

\begin{tabular}{|c|c|c|c|c|c|c|}
\hline No. & \multicolumn{2}{|c|}{ Interview } & Ratter 1 & Ratter 2 & Kappa & $\%$ \\
\hline 7 & \multicolumn{2}{|c|}{ Interview no. 2} & 24 & 23 & 0.34 & $96 \%$ \\
\hline 8 & \multicolumn{2}{|c|}{ Interview no. 4} & 50 & 48 & 0.65 & $96 \%$ \\
\hline 9 & \multicolumn{2}{|c|}{ Interview no. 13} & 27 & 25 & 0.63 & $93 \%$ \\
\hline 10 & \multicolumn{2}{|c|}{ Interview no. 5} & 39 & 38 & 0.79 & $97 \%$ \\
\hline 11 & \multicolumn{2}{|c|}{ Interview no. 27} & 39 & 38 & 0.79 & $97 \%$ \\
\hline 12 & \multicolumn{2}{|c|}{ Interview no. 11} & 30 & 28 & 0.64 & $93 \%$ \\
\hline \multicolumn{5}{|c|}{ Average } & 0.73 & $96 \%$ \\
\hline \multicolumn{7}{|c|}{ Table 5} \\
\hline \multicolumn{2}{|c|}{ Rigour critical } & \multicolumn{2}{|l|}{$\begin{array}{l}\text { Criteria for } \\
\text { rigour }\end{array}$} & h strategy & \multicolumn{2}{|c|}{ Techniques to insure rigour } \\
\hline \multirow{6}{*}{\multicolumn{2}{|c|}{ Credibility }} & \multirow[t]{6}{*}{ Truth value } & & tes/memo & \multicolumn{2}{|c|}{$\begin{array}{l}\text { Purposeful/theoretical } \\
\text { sampling }\end{array}$} \\
\hline & & & & recorder & \multicolumn{2}{|c|}{ Negative/deviant case } \\
\hline & & & & latic log & \multicolumn{2}{|c|}{ Constant comparison } \\
\hline & & & & transcript & \multicolumn{2}{|c|}{ Member checking } \\
\hline & & & & & \multicolumn{2}{|c|}{ Triangulation } \\
\hline & & & & & \multicolumn{2}{|c|}{ Audit trial } \\
\hline \multirow{2}{*}{\multicolumn{2}{|c|}{ Transferability }} & Applicability & & display & \multicolumn{2}{|c|}{$\begin{array}{c}\text { Purposeful/theoretical } \\
\text { sampling }\end{array}$} \\
\hline & & & & $\begin{array}{l}\text { Dus literature } \\
\text { view }\end{array}$ & \multicolumn{2}{|c|}{ Thick description } \\
\hline \multirow{6}{*}{\multicolumn{2}{|c|}{ Dependability }} & Consistency & & tes/memo & \multicolumn{2}{|c|}{ Negative/deviant case } \\
\hline & & & & recorder & \multicolumn{2}{|c|}{ Member checking } \\
\hline & & & & latic $\log$ & \multicolumn{2}{|c|}{ Triangulation } \\
\hline & & & & transcript & \multicolumn{2}{|c|}{ Audit trial } \\
\hline & & & & her's story & & \\
\hline & & & & exivity & & \\
\hline \multicolumn{2}{|c|}{ Confirmability } & Neutrality & & tes/memo & \multicolumn{2}{|c|}{ Audit trial } \\
\hline
\end{tabular}

\section{Discussion}

During the semi-structured interview collection process, the result has been analysed by using simultaneous and concurrent data alongside constant comparison methods. Table 6 presents the aspects of OC compared with the literature review.

A great deal of previous research into LI has focused on communication and interaction within the firms. Communication and interaction within the firms is widely recognised as important element for LI (Achanga et al., 2005, 2006, 2012; Al-Najem et al., 2013). Communication of the objective, the direction and an outline of the proposal is a very important step at the beginning of the implementation. The company needs to 
establish a clear communication process between all employees during every stage of the implementation. Definition of the necessary actions, their communication to the employees and the identification of individual responsibilities comprise the guide for a successful LI (Al-Shammri, 2007). A successful LI is influenced by how the company will effectively communicate with those affected by the new way of doing the business (Worley and Doolen, 2006; Angelis et al., 2011; Crofton and Dale, 1996; Hu et al., 2015; Mann, 2009; Womack and Jones, 2003; Womack et al., 1992; Rand et al., 1997). For companies to success in their LI process, managers need to convey the benefits of lean, as well as, how the implementation will take place to all the members of the company (Mathaisel, 2005). Good communication plan is vital to involve everyone in the implementation process to get them committed and to identify how the implementation of lean will affect their work. Realisation of a organisation's strategy and vision process concerns both managerial and organisational issues, such as participation, communication, project management and point of entry (Löfving et al., 2014). Hence, the suggested characteristic, realisation, includes three of the former groups as defined by Platts (1994). Traditionally, organisation's strategy and vision were formulated by top management (e.g., Platts et al., 1996; Skinner, 1969). Thus, it is well known that the key mechanism for overcoming resistance to change is to include employees and allow them to participate in the formulation (Coch and French, 1948; Riis et al., 2006; Slack, 2015). As participation and resourcing cannot be neglected in a review, this is called adequate resource identification, i.e., who is responsible and who participates in the formulation (Platts et al., 1996). Platts (1994) points out the importance of both individual and group participation for achieving enthusiasm, understanding and commitment. For group participation there should be a decision-making forum and workshop-style meetings to agree on objectives, identify problems and develop improvements (Platts, 1994). An agreed timescale is another criterion (Platts et al., 1996; Baines et al., 2005). The time scale sets the limits when the project should end and defines the plan on what to do. However, there should also be clearly defined objectives and expectations of the resulting strategy and of the process (Platts et al., 1996). Boyer (1996), considered four types of investment in the manufacturing infrastructure that will enhance the infrastructure within workshop floor: quality leadership on the part of management; the use of small groups or teams for problem solving; training; and worker empowerment. Mathur et al. (2012), considered cultural change and quality improvement supported by infrastructure as CSFs for TQM in Indian SMEs manufacturing sector. In addition, The infrastructure within SMEs workshop provide with safety and health guide and allows effective communication channels across all aspects of the organisation (Bhamra et al., 2011; Baidoun, 2004). To avoid the 'dark side of quality' (Vincent, 1997), all the risks should be identified, analysed, treated and monitored (Verbano and Turra, 2010; Crema and Verbano, 2015). In addition, Achieving excellent quality with minimum utilisation of resources and cost with applying feedback system is ultimate purpose and achieved (Jadhav et al., 2015). The US manufacturing industry has made significant progress in increasing productivity, product quality while lowering product lead times, Increased variety of products, Increased flexibility of manufacturing operations, encourage employees to develop a sense of responsibility for quality and helps to reduce workplace health and safety risks (Camuffo et al., 2017; Salem and Zimmer, 2005; Womack et al., 1992). In addition employee empowerment in manufacturing found its most profound application in the idea that any employee could 'stop the line' if he or she noticed a quality problem (Salem and Zimmer, 2005). 
Table 6 Aspects of OC

\begin{tabular}{|c|c|c|}
\hline No. & Aspects of organisational culture & References \\
\hline 1 & Job description & Jadhav et al. (2015) \\
\hline 2 & Health and safety awareness & Munene (1995) and Dixon (1999) \\
\hline 3 & Quality of inspection & Crofton and Dale (1996) \\
\hline 4 & Professional training in lean & $\begin{array}{l}\text { Allen and Meyer (1997), Achanga et al. (2006) } \\
\text { and Panizzolo et al. (2012) }\end{array}$ \\
\hline 5 & Many decision makers & $\begin{array}{l}\text { Angelis and Fernandes (2007), Mann (2009) and } \\
\text { Hu et al. (2015) }\end{array}$ \\
\hline 6 & Role of the family & Al-Najem (2014) \\
\hline 7 & Knowledge share & $\begin{array}{l}\text { Rand et al. (1997), Shah (2003), Womack and } \\
\text { Jones (2003), Shah and Ward (2007) and Angelis } \\
\text { et al. (2011) }\end{array}$ \\
\hline 8 & Poor planning & $\begin{array}{l}\text { Crofton and Dale (1996), Rand et al. (1997) and } \\
\text { Womack and Jones (2003) }\end{array}$ \\
\hline 9 & Short-term focus & $\begin{array}{l}\text { Bhasin and Burcher (2006), Bhasin (2012) and } \\
\text { Laureani and Antony (2016) }\end{array}$ \\
\hline 10 & Motivation and reward system & Angelis et al. (2011) and Alsyouf et al. (2011) \\
\hline 11 & Promotional opportunities & Angelis et al. (2011) \\
\hline 12 & Recruitment process & $\begin{array}{l}\text { Allen and Meyer (1997) and Womack et al. } \\
\text { (1992) }\end{array}$ \\
\hline 13 & Workshop tools and guidance & Shah (2003) and Shah and Ward (2007) \\
\hline 14 & Delay in processing staff requests & Angelis et al. (2011) \\
\hline 15 & Resistance of change & $\begin{array}{l}\text { Bhamu and Sangwan (2014) and Jadhav et al. } \\
\text { (2014) }\end{array}$ \\
\hline 16 & Ineffective multi-tasking & Bessant and Caffyn (1997) \\
\hline 17 & Feedback system & $\begin{array}{l}\text { Angelis et al. (2011), Rand et al. (1997), Shah } \\
\text { (2003), Womack and Jones (2003), Shah and } \\
\text { Ward (2007) and Angelis et al. (2011) }\end{array}$ \\
\hline 18 & Improper prioritisation of tasks & Swank (2003) \\
\hline 19 & Performance indicators & $\begin{array}{l}\text { Shah (2003), Shah and Ward (2007) and } \\
\text { Yan-Jiang et al. (2006) }\end{array}$ \\
\hline 20 & Contingency planning & Crofton and Dale (1996) \\
\hline 21 & Teamwork and leadership attitude & $\begin{array}{l}\text { Womack et al. (1992) and Laureani and Antony } \\
\text { (2016) }\end{array}$ \\
\hline 22 & Job security & Marodin and Saurin (2013) \\
\hline 23 & Aggression on the shop floor & $\begin{array}{l}\text { Hu et al. (2015), Angelis et al. (2011), Mann } \\
\text { (2009) and Al-Najem et al. (2012) }\end{array}$ \\
\hline 24 & Productivity monitoring & Bessant and Caffyn (1997) and Swank (2003) \\
\hline 25 & $\begin{array}{l}\text { Cooperation and mutual trust } \\
\text { between management employees }\end{array}$ & Jadhav et al. (2014) \\
\hline 26 & Bureaucratic management & $\begin{array}{l}\text { Al-Najem et al. (2012) and Laureani and Antony } \\
\text { (2016) }\end{array}$ \\
\hline 27 & Innovation management. & Jadhav et al. (2015) \\
\hline
\end{tabular}


Table 6 Aspects of OC (continued)

\begin{tabular}{lll}
\hline No. & Aspects of organisational culture & \\
\hline 28 & Loyalty of the staff & $\begin{array}{l}\text { Al-Najem (2014) and Dahlgaard and } \\
\text { Mi Dahlgaard-Park (2006) } \\
\end{array}$ \\
29 & Research and development (R\&D) & (Not found) \\
30 & $\begin{array}{l}\text { Emphasis on the individual } \\
\text { contribution }\end{array}$ & (Not found) \\
31 & System of decision-making & Angelis et al. (2011) \\
32 & Socialisation of the staff & (Not found) \\
33 & Emotional intelligence of managers & Dahlgaard and Mi Dahlgaard-Park (2006) \\
34 & Workload pressure & Jadhav et al. (2014) \\
35 & Ambiguity of policies & Hu et al. (2015) \\
36 & Obligatory work & (Not found) \\
37 & Identification of resources & Jadhav et al. (2014), Marodin and Saurin (2013) \\
& & and Laureani and Antony (2016) \\
\hline
\end{tabular}

Employee empowerment and involvement in lean implantation as the key success factor as the focus is on 'teamwork'. In addition, given a strategic role in the process based on changes required for increased commitment and empowering of the employees and cross training, human resource management practices have been considered effective instruments to improve employees' abilities, motivation, opportunities, and ultimately to ameliorate operational and social performance (Arnaud and Wasieleski, 2014; Camuffo et al., 2017; Kochan et al., 1997; MacDuffie and Helper, 1997).

\section{Conclusions}

In conclusion, the paper aims to identify enablers and inhibitors of LI in SMEs in the KSA. It proposes aspects of social transformation process and how the aspects are affected by OC. The paper opted for an exploratory study using semi-structure interviews, focus groups and observation approaches of grounded theory and action research. 29 in-depth interviews with employees ranging in terms of their position in the organisations, having mainly an experience of the LI background. The data was complemented by context analysis, including simultaneous and concurrent data collection and constant comparison methods. The paper provides empirical insights about how change is brought about during implementing lean. However, there were four aspects which have not been evidenced in prior research and were not identified in the literature review. These include; research and development (R\&D), emphasis on individual contributions, socialisation of staff and obligatory work. 37 aspects have been identified from semi-structured interviews. All these aspects have been aggregated through focus groups to seven main themes. This paper fulfils an identified need to study how the OC affects LI. It contributes to the current state of LI in manufacturing companies by uncovering the correlation between enablers and inhibitors of OC in Saudi Arabia.

This study is a part of a developing framework to facilitate LI within SMEs and manufacturing companies by leveraging aspects of OC. 


\section{References}

Achanga, P., Shehab, E., Roy, R. and Nelder, G. (2005) 'Lean manufacturing for SMEs: enabling rapid response to demand changes', in International Conference on Engineering Design, pp.15-18.

Achanga, P., Shehab, E., Roy, R. and Nelder, G. (2006) 'Critical success factors for lean implementation within SMEs', Journal of Manufacturing Technology Management, Vol. 17, No. 4, pp.460-471, DOI: 10.1108/17410380610662889.

Achanga, P., Shehab, E., Roy, R. and Nelder, G. (2012) 'A fuzzy-logic advisory system for lean manufacturing within \{SMEs\}', International Journal of Computer Integrated Manufacturing, Vol. 25, No. 9, pp.839-852, Informa Limited, UK, DOI: 10.1080/0951192x.2012.665180.

Ahmed, P.K., Loh, A.Y.E. and Zairi, M. (1999) 'Cultures for continuous improvement and learning’, Total Quality Management, Vol. 10, Nos. 4-5, pp.426-434, DOI: 10.1080/ 0954412997361.

Allen, N. and Meyer, J. (1997) Commitment in the Workplace: Theory, Research and Application, Thousand Oaks.

Al-Najem, M. (2014) Investigating the Factors Affecting Readiness for Lean System Adoption within Kuwaiti Small And Medium-Sized Manufacturing Industries, University of Portsmouth, UK.

Al-Najem, M., Dhakal, H. and Bennett, N. (2012) 'The role of culture and leadership in lean transformation: a review and assessment mode', International Journal of Lean Thinking, Vol. 3, No. 1, pp.119-138.

Al-Najem, M., Dhakal, H., Labib, A. and Bennett, N. (2013) 'Lean readiness level within Kuwaiti manufacturing industries', International Journal of Lean Six Sigma, Vol. 4, No. 3, pp.280-320, DOI: 10.1108/IJLSS-05-2013-0027.

Al-Shammri, M. (2007) How to Successfully Implement Lean, Cranfield University, UK.

Al-Swidi, A. and Mahmood, R. (2011) 'How does organizational culture shape the relationship between entrepreneurial orientation and the organizational performance of banks?', European Journal of Social Sciences, Vol. 20, No. 1, pp.28-46.

Angelis, J., Conti, R., Cooper, C. and Gill, C. (2011) 'Building a high-commitment lean culture', Journal of Manufacturing Technology Management, Vol. 22, No. 5, pp.569-586, DOI: $10.1108 / 17410381111134446$.

Angelis, J.J. and Fernandes, B. (2007) 'Lean practices for product and process improvement: involvement and knowledge capture', in Advances in Production Management Systems, pp.347-354, Springer, Boston, MA, USA, DOI: 10.1007/978-0-387-74157-4_41.

Annells, M. (1996) 'Grounded theory method: philosophical perspectives, paradigm of inquiry, and postmodernism', Qualitative Health Research, Vol. 6, No. 3, pp.379-393, DOI: 10.1177/ 104973239600600306.

Arnaud, S. and Wasieleski, D.M. (2014) 'Corporate humanistic responsibility: social performance through managerial discretion of the HRM', Journal of Business Ethics, Vol. 120, No. 3, pp.313-334, DOI: 10.1007/s10551-013-1652-z.

Babbie, E. (2015) The Practice of Social Research, Wadsworth Cengage Learning, USA.

Baidoun, S. (2004) 'The implementation of TQM philosophy in Palestinian organization: a proposed non-prescriptive generic framework', The TQM Magazine, Vol. 16, No. 3, pp.174-185, DOI: 10.1108/09544780410532909.

Baines, T., Kay, G., Adesola, S. and Higson, M. (2005) 'Strategic positioning: an integrated decision process for manufacturers', International Journal of Operations \& Production Management, Vol. 25, No. 2, pp.180-201, DOI: 10.1108/01443570510577029.

Bessant, J. and Caffyn, S. (1997) 'High-involvement innovation through continuous improvement', International Journal of Technology Management, Vol. 14, No. 1, p.7, DOI: 10.1504/IJTM.1997.001705. 
Bhamra, R., Dani, S. and Bhamra, T. (2011) 'Competence understanding and use in SMEs: a UK manufacturing perspective', International Journal of Production Research, Vol. 49, No. 10, pp.2729-2743, DOI: 10.1080/00207541003738873.

Bhamu, J. and Sangwan, K.S. (2014) 'Lean manufacturing: literature review and research issues', International Journal of Operations \& Production Management, Vol. 34, No. 7, pp.876-940, Emerald Group Publishing Ltd., DOI: 10.1108/IJOPM-08-2012-0315.

Bhasin, S. (2012) 'Prominent obstacles to lean', International Journal of Productivity and Performance Management, Vol. 61, No. 4, pp.403-425, Emerald Group Publishing Limited, DOI: $10.1108 / 17410401211212661$.

Bhasin, S. and Burcher, P. (2006) 'Lean viewed as a philosophy', Journal of Manufacturing Technology Management, Vol. 17, No. 1, pp.56-72, DOI: 10.1108/17410380610639506.

Birkinshaw, J., Brannen, M.Y. and Tung, R.L. (2011) 'From a distance and generalizable to up close and grounded: Reclaiming a place for qualitative methods in international business research', Journal of International Business Studies, Vol. 42, No. 5, pp.573-581, DOI: 10.1057/jibs.2011.19.

Bogdan, R. and Biklen, S.K. (2007) Qualitative Research for Education: An Introduction to Theories and Methods, Pearson A \& B.

Boyer, K.K. (1996) 'An assessment of managerial commitment to lean production', International Journal of Operations \& Production Management, Vol. 16, No. 9, pp.48-59, DOI: $10.1108 / 01443579610125589$.

Bryant, A. (2009) 'Grounded theory and pragmatism: the curious case of anselmstrauss', Forum Qualitative Sozialforschung, Vol. 10, No. 3, DOI: http://nbn-resolving.de/urn:nbn:de:0114fqs090325.

Calabrò, A. and Mussolino, D. (2013) 'How do boards of directors contribute to family SME export intensity? The role of formal and informal governance mechanisms', Journal of Management \& Governance, Vol. 17, No. 2, pp.363-403, DOI: 10.1007/s10997-011-9180-7.

Camuffo, A., De Stefano, F. and Paolino, C. (2017) 'Safety reloaded: lean operations and high involvement work practices for sustainable workplaces', Journal of Business Ethics, Vol. 143, No. 2, pp.245-259, Springer Netherlands, DOI: 10.1007/s10551-015-2590-8.

Chase, N. (1999) 'Lose the waste: get lean!', Quality, Vol. 38, No. 3, pp.34-39.

Chay, T., Xu, Y., Tiwari, A. and Chay, F. (2015) 'Towards lean transformation: the analysis of lean implementation frameworks', Journal of Manufacturing Technology Management, Vol. 26, No. 7, pp.1031-1052, DOI: 10.1108/JMTM-10-2013-0143.

Chiarini, A. (2012) 'Lean production: mistakes and limitations of accounting systems inside the SME sector', in Bates, K. (Ed.): Journal of Manufacturing Technology Management, Vol. 23, No. 5, pp.681-700, DOI: 10.1108/17410381211234462.

Coch, L. and French, J.R.P. (1948) 'Overcoming resistance to change', Human Relations, Vol. 1, No. 4, pp.512-532, DOI: 10.1177/001872674800100408.

Coghlan, D. and Brannick, T. (2014) Doing Action Research in your Own Organization, Sage.

Collis, J. and Hussey, R. (2013) Business Research: A Practical Guide for Undergraduate and Postgraduate Students, Palgrave Macmillan.

Cooney, R. (2002) 'Is ‘lean’ a universal production system?’, International Journal of Operations \& Production Management, Vol. 22, No. 10, pp.1130-1147, MCB UP Ltd., DOI: $10.1108 / 01443570210446342$.

Corbett, S. (2007) 'Beyond manufacturing: the evolution of lean production', McKinsey Quarterly, Vol. 3, pp.94-96.

Corbin, J. and Strauss, A. (1990) Basics of Qualitative Research: Grounded Theory Procedures and Techniques, Basics of Qualitative Research, Sage, UK.

Corbin, J. and Strauss, A. (2008) Basics of Qualitative Research, 3rd ed., Techniques and Procedures for Developing Grounded Theory, Basics of Qualitative Research: Grounded Theory Procedures and TECHNIQUES, Newbury, 2455 Teller Road, Thousand Oaks California 91320, SAGE Publications, Inc., USA, DOI: 10.4135/9781452230153. 
Crema, M. and Verbano, C. (2015) 'Investigating the connections between health lean management and clinical risk management', International Journal of Health Care Quality Assurance, Vol. 28, No. 8, pp.791-811, DOI: 10.1108/IJHCQA-03-2015-0029.

Creswell, J. (2013) Research Design: Qualitative, Quantitative, and Mixed Methods Approaches, Sage Publications, UK.

Crofton, C.G. and Dale, B.G. (1996) 'The difficulties encountered in the introduction of total quality management: a case study examination', Quality Engineering, Vol. 8, No. 3, pp.433-439, Taylor \& Francis Group, DOI: 10.1080/08982119608904645.

Cusumano, M. (1994) ‘The limits of 'lean’, Sloan Management Review, Vol. 34, No. 4, p.27.

Dahlgaard, J.J. and Mi Dahlgaard-Park, S. (2006) 'Lean production, six sigma quality, TQM and company culture', in Mi Dahlgaard-Park, S. (Ed.): The TQM Magazine, Vol. 18, No. 3, pp.263-281, DOI: 10.1108/09544780610659998.

Dey, I. (1999) Grounding Grounded Theory: Guidelines for Qualitative Inquiry, Academic Press, UK.

Dick, B. (2006) Grounded Theory: A Thumbnail Sketch [online] http://www.aral.com.au/resources/ grounded.html (accessed 12 August 2017).

Dixon, N.M. (1999) The Organizational Learning Cycle: How We Can Learn Collectively, Gower Publishing, Ltd., London.

Fisher, C. (2007) Researching and Writing a Dissertation Business Students, p.359, Pearson Education Limited.

Glaser, B. and Strauss, A. (1967) 'The discovery of grounded theory', Strategies for Qualitative Research, Weidenfeld, London.

Golden-Biddle, K. and Locke, K. (2007) Composing Qualitative Research, 2nd ed., Sage Publications Inc.

Goulding, C. (1998) 'Grounded theory: the missing methodology on the interpretivist agenda', Qualitative Market Research: An International Journal, Vol. 1, No. 1, pp.50-57, DOI: $10.1108 / 13522759810197587$.

Goulding, C. (2005) 'Grounded theory, ethnography and phenomenology', in Lee, N. (Ed.): European Journal of Marketing, Vol. 39, Nos. 3/4, pp.294-308, DOI: 10.1108/ 03090560510581782.

Guba, E. and Lincoln, Y. (1994) 'Competing paradigms in qualitative research', Handbook of Qualitative Research, SAGE Publications, London.

Gwet, K. (2002) 'Kappa statistic is not satisfactory for assessing the extent of agreement between raters', Statistical Methods for Inter-Rater Reliability Assessment, Vol. 1, No. 6, pp.1-6.

Hines, P., Holweg, M. and Rich, N. (2004) 'Learning to evolve', International Journal of Operations $\{\&\}$ Production Management, Vol. 24, No. 10, pp.994-1011, Emerald, DOI: $10.1108 / 01443570410558049$.

Hu, Q., Mason, R., Williams, S.J. and Found, P. (2015) 'Lean implementation within SMEs: a literature review', Journal of Manufacturing Technology Management, Vol. 26, No. 7, pp.980-1012, DOI: 10.1108/JMTM-02-2014-0013.

Ibrahim, U. (2013) Investigating the Effects of Corporate Governance of Banks in Nigeria: A Grounded Theory Approach, Plymouth University, UK.

Im, J.H. and Lee, S.M. (1989) 'Implementation of just-in-time systems in US manufacturing firms', International Journal of Operations \& Production Management, Vol. 9, No. 1, pp.5-14, DOI: 10.1108/EUM0000000001213.

Jadhav, J.R., Mantha, S.S. and Rane, S.B. (2014) 'Exploring barriers in lean implementation', International Journal of Lean Six Sigma, Vol. 5, No. 2, pp.122-148, DOI: 10.1108/IJLSS-122012-0014.

Jadhav, J.R., Mantha, S.S. and Rane, S.B. (2015) 'Roadmap for lean implementation in Indian automotive component manufacturing industry: comparative study of UNIDO Model and ISM 
model', Journal of Industrial Engineering International, Vol. 11, No. 2, pp.179-198, DOI: 10.1007/s40092-014-0074-6.

James-Moore, S.M. and Gibbons, A. (1997) 'Is lean manufacture universally relevant? An investigative methodology', International Journal of Operations \& Production Management, Vol. 17, No. 9, pp.899-911, MCB UP Ltd., DOI: 10.1108/01443579710171244.

Karim, M.A., Aljuhani, M., Duplock, R. and Yarlagadda, P. (2011) 'Implementation of lean manufacturing in Saudi manufacturing organisations: an empirical study', Advanced Materials Research, Vol. 339, pp.250-253, DOI: 10.4028/www.scientific.net/AMR.339.250.

Kochan, T., Lansbury, R. and Macduffie, J. (1997) After Lean Production: Evolving Employment Practices in the World Auto Industry', Cornell University Press, New York.

Kolb, S.M. (2012) 'Grounded theory and the constant comparative method: valid research strategies for educators', Journal of Emerging Trends in Educational Research and Policy Studies, Vol. 3, No. 1, pp.83-86.

Lathin, D. and Mitchell, R. (2001) 'Lean manufacturing: techniques, people and culture', in ASQ World Conference on Quality and Improvement Proceedings, p.321.

Laureani, A. and Antony, J. (2016) 'Leadership - a critical success factor for the effective implementation of lean Six Sigma', in Setijono, D. (Ed.): Total Quality Management \& Business Excellence, Vol. 3, No. 4, pp.1-22, DOI: 10.1080/14783363.2016.1211480.

Lewis, M.A. (2000) 'Lean production and sustainable competitive advantage', International Journal of Operations \& Production Management, Vol. 20, No. 8, pp.959-978, DOI: $10.1108 / 01443570010332971$.

Liker, J. (1997) 'Becoming lean: Inside stories of US manufacturers', Quality Progress, Vol. 32, No. 3, p.107, Productivity Press.

Lin, Z. and Hui, C. (1999) 'Should lean replace mass organization systems? A comparative examination from a management coordination perspective', Journal of International Business Studies, Vol. 30, No. 1, pp.45-79.

Locke, K. (2001) Grounded Theory in Management Research, Sage, London.

Löfving, M., Säfsten, K. and Winroth, M. (2014) 'Manufacturing strategy frameworks suitable for SMEs', Journal of Manufacturing Technology Management, Vol. 25, No. 1, pp.7-26, DOI: 10.1108/JMTM-08-2012-0081.

MacDuffie, J.P. and Helper, S. (1997) 'Creating lean suppliers: diffusing lean production through the supply chain’, California Management Review, Vol. 39, No. 4, pp.118-151.

Mann, D. (2009) 'The missing link: lean leadership', Frontiers of Health Services Management, Vol. 26, No. 2, p.15.

Marodin, G.A. and Saurin, T.A. (2013) 'Implementing lean production systems: research areas and opportunities for future studies', International Journal of Production Research, Vol. 51, No. 22, pp.6663-6680, DOI: 10.1080/00207543.2013.826831.

Mathaisel, D.F.X. (2005) 'A lean architecture for transforming the aerospace maintenance, repair and overhaul (MRO) enterprise', International Journal of Productivity and Performance Management, Vol. 54, No. 8, pp.623-644, DOI: 10.1108/17410400510627499.

Mathur, A., Mittal, M.L. and Dangayach, G.S. (2012) 'Improving productivity in Indian SMEs', Production Planning \& Control, Vol. 23, Nos. 10-11, pp.754-768, Informa \{UK\} Limited, DOI: $10.1080 / 09537287.2011 .642150$.

Miles, M. and Huberman, A. (1994) Qualitative Data Analysis: An Expanded Sourcebook, Sage [online] https://scholar.google.co.uk/scholar?hl=en\&q=Qualitative+data+analysis\%3A+An+ expanded+source+book\&btnG=\&as_sdt=1\%2C5\&as_sdtp=\#0 (accessed 16 April 2016).

Munene, J. (1995) 'NNot-on-seat': an investigation of some correlates of organisational citizenship behaviour in Nigeria’, Applied Psychology, Vol. 44, No. 2, pp.111-122, DOI: 10.1111/j.14640597.1995.tb01069.x.

Narasimhan, R., Kull, T.J. and Nahm, A. (2012) 'Alternative relationships among integrative beliefs, time-based manufacturing and performance', International Journal of Operations \& 
Production Management, Vol. 32, No. 4, pp.496-524, Emerald Group Publishing Limited, DOI: $10.1108 / 01443571211223112$.

Oliver, N. and Hunter, G. (1998) The Financial Impact of 'Japanese' Manufacturing Methods, Manufacturing In Transition, Routlege \& Kegan Paul, London.

Pakdil, F. and Leonard, K.M. (2015) 'The effect of organizational culture on implementing and sustaining lean processes', Journal of Manufacturing Technology Management, Vol. 26, No. 5, pp.725-743, DOI: 10.1108/JMTM-08-2013-0112.

Panizzolo, R., Garengo, P., Sharma, M.K. and Gore, A. (2012) 'Lean manufacturing in developing countries: evidence from Indian SMEs’, Production Planning \& Control, Vol. 23, Nos. 10-11, pp.769-788, DOI: 10.1080/09537287.2011.642155.

Patton, M.Q. (2014) Qualitative Research \& Evaluation Methods: Integrating Theory and Practice: Integrating Theory and Practice, Sage Publications, London.

Pay, R. (2008) 'Everybody's jumping on the lean bandwagon, but many are being taken for a ride', Industry Week, May, pp.21-23.

Platts, K.W. (1994) 'Characteristics of methodologies for manufacturing strategy formulation', Computer Integrated Manufacturing Systems, Vol. 7, No. 2, pp.93-99, DOI: 10.1016/09515240(94)90003-5.

Platts, K.W., Mills, J.F., Neely, A.D., Gregory, M.J. and Richards, A.H. (1996) 'Evaluating manufacturing strategy formulation processess', International Journal of Production Economics, 46-47, pp.233-240, DOI: 10.1016/0925-5273(95)00029-1.

Rand, G., Womack, J. and Jones, D.T. (1997) 'Lean thinking - banish waste and create wealth in your corporation', The Journal of the Operational Research Society, JSTOR, Vol. 48, No. 11, p.1148, DOI: $10.2307 / 3010314$.

Rashid, H. (2010) Human Factors Effects in Helicopter Maintenance: Proactive Monitoring and Controlling Techniques, Cranfield University, UK.

Riis, J.O., Dukovska-Popovska, I. and Johansen, J. (2006) 'Participation and dialogue in strategic manufacturing development', in Production Planning and Control, pp.176-188, DOI: $10.1080 / 09537280500224085$.

Rose, A.M.N., Deros, B.M. and Rahman, M.N.A. (2010) 'Development of framework for lean manufacturing implementation in SMEs', The 11th Asia Pacific Industrial Engineering and Management Systems Conference, December, pp.7-10.

Sackmann, S. (1991) 'Uncovering culture in organizations', The Journal of Applied Behavioral Science, Vol. 27, No. 3, pp.295-317.

Sackmann, S. (2006) Success Factor: Corporate Culture: Developing A Corporate Culture for High Performance and Long Term Competitiveness: Six Best Practices, Verlag Bertelsmann Stiftung, Gütersloh.

Salem, O. and Zimmer, E. (2005) 'Application of lean manufacturing principles to construction', Lean Construction Journal, Vol. 2, No. 2, pp.51-54.

Salem, R., Musharavati, F., Hamouda, A.M. and Al-Khalifa, K.N. (2016) 'An empirical study on lean awareness and potential for lean implementations in Qatar industries', The International Journal of Advanced Manufacturing Technology, Vol. 82, Nos. 9-12, pp.1607-1625, DOI: $10.1007 / \mathrm{s} 00170-015-7421-7$.

Schein, E. (1985) 'How culture forms, develops, and changes', Gaining Control of the Corporate Culture, pp.17-43 [online] https://scholar.google.co.uk/scholar?q=How+Culture+Forms\% 2C+Develops+and + Changes\&btnG $=\& h l=e n \& a s \_s d t=0 \% 2 C 5 \# 0$.

Schouteten, R. and Benders, J. (2004) 'Lean production assessed by Karasek’s job demand-job control model', Economic and Industrial Democracy, Vol. 25, No. 3, pp.347-373, DOI: $10.1177 / 0143831$ X04044831.

Shah, R. (2003) 'Lean manufacturing: context, practice bundles, and performance', Journal of Operations Management, Vol. 21, No. 2, pp.129-149, DOI: 10.1016/S0272-6963(02)00108-0. 
Shah, R. and Ward, P.T. (2007) 'Defining and developing measures of lean production', Journal of Operations Management, Vol. 25, No. 4, pp.785-805, DOI: 10.1016/j.jom.2007.01.019.

Silverman, D. (2006) Interpreting Qualitative Data: Methods for Analyzing Talk, Text and Interaction, 3rd ed., Sage, Los Angeles.

Skinner, W. (1969) 'Manufacturing - missing link in corporate strategy', Harvard Business Review, Vol. 47, No. 3, pp.136-145, DOI: 10.5465/AMR.2007.23466005.

Slack, N. (2015) 'Operations strategy', in Wiley Encyclopedia of Management, pp.1-2, John Wiley \& Sons, Ltd., Chichester, UK, DOI: 10.1002/9781118785317.weom100160.

Srubar, I. (1998) 'Phenomenological analysis and its contemporary significance', Human Studies, Vol. 21, No. 2, pp.121-139, DOI: 10.1023/A:1005355921478.

Strauss, A. (1987) Qualitative Analysis for Social Scientists, Cambridge University Press [online] https://books.google.co.uk/books?hl=en\&lr=\&id=y16ww5ZsJ0AC\&oi=fnd\&pg=PA109\&dq= Qualitative+analysis+for+social+scientists\&ots=gV8wNShaiS\&sig=t65cOdLOiuvOImCBO8 7_UKCYBWI (accessed 16 April 2016).

Strauss, A. and Corbin, J. (1994) 'Grounded theory methodology', Handbook of Qualitative Research, pp.273-285.

Swank, C. (2003) 'The lean service machine', Harvard Business Review, Vol. 81, No. 10, pp.123-130.

Taylor, G.R. (2005) Integrating Quantitative and Qualitative Methods in Research, University Press of America.

Trochim, W. and Donnelly, J. (2001) 'Research methods knowledge base'.

Verbano, C. and Turra, F. (2010) 'A human factors and reliability approach to clinical risk management: evidence from Italian cases’, Safety Science, Vol. 48, No. 5, pp.625-639, DOI: 10.1016/j.ssci.2010.01.014.

Vincent, C. (1997) 'Risk, safety, and the dark side of quality', British Medical Journal, Vol. 314, No. 7097, pp.1775-1776.

Walker, D. and Myrick, F. (2006) 'Grounded theory: an exploration of process and procedure', Qualitative Health Research, Vol. 16, No. 4, pp.547-559, DOI: 10.1177/1049732305285972.

Wang, Y. and Huzzard, T. (2011) 'The impact of lean thinking on organizational learning', OLKC 2011 - Making Waves, Conference, pp.1-19.

Willis, J., Jost, M. and Nilakanta, R. (2007) Foundations of Qualitative Research: Interpretive and Critical Approaches, SAGE Publications, Sage.

Wittenberg, G. (1994) 'Kaizen - the many ways of getting better’, Assembly Automation, Vol. 14, No. 4, pp.12-17, DOI: 10.1108/EUM0000000004213.

Womack, J. and Jones, D.T. (2003) Lean Thinking: Banish Waste And Create Wealth In Your Corporation, 2nd ed., Simon and Schuster, New York.

Womack, J.P., Jones, D.T. and Roos, D. (1992) 'The machine that changed the world', Business Horizons, Vol. 35, No. 3, pp.81-82, DOI: 10.1016/0007-6813(92)90074-J.

Worley, J.M. and Doolen, T.L. (2006) 'The role of communication and management support in a lean manufacturing implementation’, in Cassell, C. (Ed.): Management Decision, Vol. 44, No. 2, pp.228-245, DOI: 10.1108/00251740610650210.

Xu, L.X.X., Wang, F.Y., Lim, R., Toh, M.H. and Valliappan, R. (2013) 'Lean implementation in small and medium enterprises 2014; a Singapore context', in 2013 IEEE International Conference on Industrial Engineering and Engineering Management, IEEE, pp.1592-1596, DOI: 10.1109/IEEM.2013.6962678.

Yamamoto, Y. and Bellgran, M. (2010) 'Fundamental mindset that drives improvements towards lean production', Assembly Automation, Vol. 30, No. 2, pp.124-130, DOI: 10.1108/ 01445151011029754. 
2018-12-31

\title{
Explore and evaluate organisational
}

culture aspects that affecting Lean implementation within manufacturing SMEs: the case of Saudi Arabia

\author{
Alkhoraif, Abdullah
}

Inderscience

Alkhoraif A, McLaughlin P. (2020) Explore and evaluate organisational culture aspects that affecting Lean implementation within manufacturing SMEs: the case of Saudi Arabia.

International Journal of Services and Operations Management, Volume 36, Issue 2, May 2020,

pp. 247-270

https://doi.org/10.1504/IJSOM.2020.10017447

Downloaded from Cranfield Library Services E-Repository 